\title{
Strategy for Increasing Traditional Market Competitiveness in Dealing with the Presence of Modern Market
}

\author{
By: \\ Syaeful Bakhri \\ Faculty of Sharia and Islamic Economics, IAIN Syekh Nurjati Cirebon \\ Email: zulfatussaada@gmail.com
}

\begin{abstract}
Modern market growth in Indonesia showed significant figure compared to the growth of the traditional markets. The shrinking of the traditional market and modern market growth was also due to the rising living standards and changing lifestyles of people, as well as the desire for comfort, freedom, guarantee low price and good quality into consideration of the public. The purpose of this research was to analyze the impact of the modern market to traditional market traders. The analysis used in this research was a quantitative analysis with Difference-in-Difference (DiD) method, analysis using different test (t-test) with Wilcoxon, Buyer Perception Analysis, and Analytical Hierarchy Process (AHP). Based on the results of analysis using DID (Difference-in-Difference) by comparing market treatment and control markets, it was found that the impact of the presence of a modern market to traditional market traders evidenced by the decrease in the average turnover of the traditional market traders reaching $(-7.8 \%)$, the average profit $(-9.39 \%)$, the number of buyers $(-12.3 \%)$, and a decrease in the number of workers in traditional markets $(-2.50 \%)$. Meanwhile, the results of the analytical hierarchy process (AHP) indicated that there were several aspects to improve the traditional market competitiveness according to priority measures to be carried out in the first place, namely the local government support (29.43\%), facilities and infrastructure (23.96\%), the market management $(20.60 \%)$, finance $(15.02 \%)$ and merchandise inventory in the last rank (10.98\%).
\end{abstract}

Keywords: Traditional Market Competitiveness, Local Government Support, Market Management, Finance, Traditional Market Traders.

\begin{abstract}
ABSTRAK
Pertumbuhan pasar modern di Indonesia menunjukkan angka yang signifikan dibandingkan dengan pertumbuhan pasar tradisional. Berkurangnya pasar tradisional dan pertumbuhan pasar modern juga disebabkan oleh meningkatnya standar hidup dan perubahan gaya hidup orang-orang, serta keinginan untuk kenyamanan, kebebasan, jaminan harga murah dan kualitas yang baik menjadi pertimbangan publik. Tujuan dari penelitian ini adalah untuk menganalisis dampak pasar modern terhadap pedagang pasar tradisional. Analisis yang digunakan dalam penelitian ini adalah analisis kuantitatif dengan metode Difference-in-Difference (DiD), analisis menggunakan uji beda (t-test) dengan Wilcoxon, Analisis Persepsi Pembeli, dan Analytical Hierarchy Process (AHP). Berdasarkan hasil analisis menggunakan DID (Difference-in-Difference) dengan membandingkan pasar perlakuan dan pasar kontrol, ditemukan bahwa dampak dari kehadiran pasar modern terhadap pedagang pasar tradisional dibuktikan dengan penurunan rata-rata omset dari pedagang pasar tradisional mencapai $(-7,8 \%)$, laba ratarata (-9,39\%), jumlah pembeli (-12,3\%), dan penurunan jumlah pekerja di pasar tradisional (-2,50\%). Sementara itu, hasil dari proses hierarki analitis (AHP) menunjukkan bahwa ada beberapa aspek untuk meningkatkan daya saing pasar tradisional sesuai dengan langkah-langkah prioritas yang harus dilakukan di tempat pertama, yaitu
\end{abstract}


dukungan pemerintah daerah (29,43\%), sarana dan prasarana (23,96\%), manajemen pasar $(20,60 \%)$, keuangan $(15,02 \%)$ dan persediaan barang dagangan di peringkat terakhir (10,98\%).

Kata Kunci: Daya Saing Pasar Tradisional, Dukungan Pemerintah Daerah, Manajemen Pasar, Keuangan, Pedagang Pasar Tradisional.

\section{INTRODUCTION}

Various types of modern markets are like mushrooms in the rainy season. Clean, neat and comfortable modern market atmosphere can attract people to shop. The shrinking of traditional markets and the growing of modern markets are also due to the rising standard of living and the changing lifestyle of society (Hermuningsih et al., 2016). The desire to obtain comfort, freedom, and guarantee of low price and good quality become a consideration of the public. Along with that, it is undeniable that the existence of modern markets has become the demands and consequences of the modern lifestyle developing in our society (Haryotejo, 2014). Meanwhile, the traditional market image perceived as slum, muddy, disorganized arrangement, and bad odor market gradually began to be abandoned by the society (Agung, 2013).

In the era of regional autonomy, for Cirebon Regency, the presence of modern market is a component supporting the availability of regional economic facilities. Based on the geostrategic location of the region in the national and regional economic lanes (north coast road in Java), Cirebon Regency is a transit area for the mobilization of people from Jakarta or Bandung to Central Java and East Java and as a supporting area of the National Activity Center (PKN), while demographically, Cirebon has the population reaching 2,309,809 people by the end of 2015. Under these conditions, Cirebon Regency has the potential and opportunity for the growth and development of modern market (Alfanita et al., 2015).

Now, the existence of modern market has become part of the socio-economic life of the people of Cirebon Regency. The development of modern market in Cirebon Regency has an effect on the condition and existence of traditional market. As a typical entity of the socio-economic life of wong cilik (common people), the presence of traditional markets must be maintained (Paramita and Ayuningsasi, 2013). If the traditional market has to compete with modern ones, then it will lose against the modern market (Damardjati, 2011). Meanwhile, Al (2013) states that retailers should be able to accommodate the demands of their customers regarding prices and services, those important things must be improved if they do not want to be abandoned by their customers (Pradipta and Wirawan, 2016). Therefore, this research is conducted to analyze the strategy for increasing traditional market competitiveness in dealing with the presence of modern market in Cirebon Regency.

\section{ANALYTICAL METHOD}

\section{Type of Research and Data Collection Method}

The type of this research was descriptive analytic research by combining quantitative and qualitative methods (mixed methods). According to Arikunto (2013), combined model research is a research by combining quantitative and qualitative strategies simultaneously by using a closed questionnaire consisting of multiple answers (quantitative) and open questionnaire (qualitative).

\section{Population and Sampling Technique}

The population of traditional market in Cirebon Regency is presented in Table 1 . While the population of modern market in Cirebon Regency is presented in Table 2. According to Arikunto (2013), the more samples, the more representative. The sample size received will depend on the type of research. If the research is descriptive, then the minimum sample is $10 \%$ of the population. Based on the above assumption, the number of samples taken was $10 \%$ of the total population. The 
sampling technique was performed by using 2 methods, namely Purposive Sampling and Random Sampling. The sample distribution in this research is presented in table 3.

Table 1. Population of Traditional Market Traders

\begin{tabular}{llrrrrrr}
\hline \multirow{2}{*}{ No. } & \multirow{2}{*}{ Market Name } & \multicolumn{3}{c}{ Selling Place } & \multicolumn{3}{c}{ Number of Traders } \\
\cline { 2 - 8 } & & Kiosk & Los & Stall & Kiosk & Los & Stall \\
\hline 1 & Babakan & 51 & 166 & 20 & 27 & 64 & 18 \\
2 & Cipeujeuh & 57 & 184 & 74 & 34 & 61 & 59 \\
3 & Jamblang & 127 & 288 & 160 & 69 & 107 & 135 \\
4 & Kueh Weru & 99 & - & - & 60 & - & - \\
5 & Palimanan & 394 & 169 & 150 & 151 & 39 & 159 \\
6 & Pasalaran & 329 & 648 & 288 & 204 & 323 & 288 \\
7 & Sumber & 76 & 477 & 184 & 65 & 131 & 178 \\
8 & Ciledug & 262 & 327 & 137 & 128 & 134 & 137 \\
\hline & Total & 1395 & 2259 & 1013 & 738 & 859 & 974 \\
\hline
\end{tabular}

Source: Disperindag of Cirebon Regency, 2015

Table 2. Population of Modern Market Traders

\begin{tabular}{clc} 
No. & Sub-District & Number of Modern Market \\
\hline 1 & Babakan & 7 \\
2 & Lemahabang & 5 \\
3 & Jamblang & 2 \\
4 & Plered & 15 \\
5 & Palimanan & 10 \\
6 & Weru & 8 \\
7 & Sumber & 13 \\
8 & Ciledug & 12 \\
\hline \multicolumn{3}{c}{ Total } \\
\hline Source: Disperindag and BPPT of Cirebon Regency, 2015
\end{tabular}

Table 3. Sample Distribution of Traditional and Modern Market Traders

\begin{tabular}{clcccc}
\hline \multirow{2}{*}{ No. } & \multirow{2}{*}{ Market Name } & \multicolumn{3}{c}{ Sample of Traditional Market } & Sample of Modern Market \\
\cline { 2 - 4 } & Kiosk & Los & Stall & \\
\hline 1 & Babakan & 3 & 6 & 2 & 2 \\
2 & Cipeujeuh & 6 & 16 & 6 & 1 \\
3 & Jamblang & 8 & 11 & 18 & 2 \\
4 & Kueh Weru & 8 & 0 & 0 & 2 \\
5 & Palimanan & 16 & 5 & 19 & 2 \\
6 & Pasalaran & 20 & 32 & 29 & 1 \\
7 & Sumber & 8 & 48 & 18 & 1 \\
8 & Ciledug & 13 & 14 & 14 & 2 \\
\hline \multicolumn{7}{c}{ Total } & 82 & 133 & 106 & 13
\end{tabular}

Analysis of t-Test Used Wilcoxon to Determine the Difference Of Traditional Market Trader Conditions Before and After the Presence of Modern Market

Wilcoxon match pairs test is used to test the significance of the comparative hypothesis of two samples when the data is ordinal (ordered)

(1) Quantitative analysis with Difference-in-Difference (DiD) was performed to determine the impact of the presence of modern market on traditional market traders.

(2) Buyer Perception Analysis was performed from interview result by comparing the 
perceptions between traditional market buyers and modern market buyers.

(3) Analytic Hierarchy Process (AHP) was performed to determine which strategy to be prioritized in order to improve the competitiveness of traditional market.

\section{RESULT AND DISCUSSION}

\section{Analysis of t-test of Traditional Market Traders Before and After The Presence of Modern Market}

The t-test analysis includes: number of workers, number of buyers, buyer segments, ways to attract buyers, operational capital, daily sales turnover, average daily net profit, and merchandise inventory, as described in the following table 4. Based on table 4, the result of impact evaluation analysis indicates that the number of workers assisting traders experiences a decline after the presence of modern markets in Cirebon Regency. This indicates that the presence of modern market has an impact on the number of workers assisting the traders in traditional market, especially in the category of none/selling alone and one person assisting category decreasing from $61.4 \%$ to $56.7 \%$ and one worker category decreasing from $24.9 \%$ to $22.7 \%$. Based on the analysis result of paired sample t-test, it is obtained the result of p-value of $0.000<0.05$ (alpha), meaning that there is an effect or difference between the number of assisting workers before and after the presence of modern market in the market area of Cirebon Regency.

Table 4. Analysis of T-Test of Traditional Market Traders Before and After the Presence of Modern Market

\begin{tabular}{|c|c|c|c|c|}
\hline \multirow[t]{2}{*}{ Variable } & \multicolumn{2}{|c|}{$\begin{array}{c}\text { Before The Presence of Modern } \\
\text { Market }\end{array}$} & \multicolumn{2}{|c|}{$\begin{array}{c}\text { After The Presence of Modern } \\
\text { Market }\end{array}$} \\
\hline & Amount & Percentage & Amount & Percentage \\
\hline \multicolumn{5}{|l|}{ Number of Workers } \\
\hline None/working alone & 197 & 61.4 & 182 & 56.7 \\
\hline One person & 80 & 24.9 & 73 & 22.7 \\
\hline Two people & 32 & 10.0 & 53 & 16.5 \\
\hline More than two people & 12 & 3.7 & 13 & 4.0 \\
\hline \multicolumn{5}{|l|}{ Number of Buyers } \\
\hline Higher & 89 & 27.7 & 19 & 5.9 \\
\hline Same & 225 & 70.1 & 217 & 67.6 \\
\hline Lower & 7 & 2.2 & 85 & 26.5 \\
\hline \multicolumn{5}{|l|}{ Daily Sales Turnover } \\
\hline$<$ IDR 100,000 & 87 & 27.1 & 90 & 28.0 \\
\hline IDR $101,000-500,000$ & 128 & 39.9 & 140 & 43.6 \\
\hline IDR 501,000 - 1,000,000 & 66 & 20.6 & 53 & 16.5 \\
\hline IDR $1,001,000-2,000,000$ & 22 & 6.9 & 21 & 6.5 \\
\hline IDR 2,001,000 - 4,000,000 & 12 & 3.7 & 13 & 4.0 \\
\hline$>$ IDR 4,000,000 & 6 & 1.9 & 4 & 1.2 \\
\hline \multicolumn{5}{|l|}{ Average Profit } \\
\hline$<$ IDR 25,000 per day & 64 & 19.9 & 74 & 23.1 \\
\hline IDR $26,000-100,000$ & 151 & 47.0 & 143 & 44.5 \\
\hline IDR 101,000 - 300,000 & 66 & 20.6 & 52 & 16.2 \\
\hline IDR 301,000 - 500,000 & 21 & 6.5 & 22 & 6.9 \\
\hline IDR 501,000 - 1,000,000 & 13 & 4.0 & 26 & 8.1 \\
\hline$>$ IDR $1,000,000$ & 6 & 1.9 & 4 & 1.2 \\
\hline Total & 321 & 100.0 & 321 & 100.0 \\
\hline
\end{tabular}

Based on the evaluation of impact between the number of traditional market buyers before and after the presence of modern market, it is obtained the result that there is a decline in the 
number of traditional market buyers after the presence of modern market at a distance of less than 500 meters from traditional market, both in the higher category from $27.7 \%$ to $5.9 \%$ and the same category from $70.1 \%$ to $67.6 \%$. Meanwhile, there is an increase in the number of traditional market buyers in the lower category from $2.2 \%$ to $26.5 \%$. The result of analysis based on paired sample t-test obtains the result of $p$-value of $0.000<0.05$ (alpha), meaning that there is an effect or difference in the number of traditional market buyers before and after the presence of modern market in Market Area of Cirebon Regency. This is caused by several factors, such as due to better building condition, the availability of adequate parking, shopping atmosphere, hygiene condition, and market safety in the modern market.

The result of impact evaluation of daily sales turnover on traditional market traders before and after the presence of modern market indicates that the daily sales turnover of IDR 501,000.00$1,000,000.00$ decreased from $20.6 \%$ to $16.5 \%$, daily sales turnover of IDR $1,001,000.00-2,000,000.00$ decreased from $6.9 \%$ to $6.5 \%$, and daily sales turnover of $>$ IDR $4,000,000.00$ decreased from $1.9 \%$ to $1.2 \%$. While based on the analysis result of $t$-test, it is obtained the result of $p$-value of $0.134>0.05$ (alpha), meaning that there is no effect or difference of daily sales turnovers earned by traditional market traders after the presence of modern market.

Based on the data above, it can be concluded that the daily sales turnover of traditional market traders is not affected by the presence of modern market because based on the turnover amount categories, there is a decrease and increase in turnover. This can be due to several factors, such as traditional market traders are able to compete in price and type of merchandise with the modern market because it is found that most of the main capital and traditional market traders operations derived from their own capital, so that they are able to compete in strategy to attract buyers. In the other hand, traditional market is not able to compete in terms of merchandise quality, the availability of parking lots, condition or building facilities, and the atmosphere of the buyer's convenience in shopping.

The analysis result of impact evaluation of average daily net profit on traditional traders before and after the presence of modern market obtains the average daily net profit. The average daily net profit of IDR $26,000.00-100,000.00$ decreased from $20.6 \%$ to $16.2 \%$, and the average daily net profit of $>$ IDR $1,000,000.00$ decreased from 1.9 to $1.2 \%$. Based on paired sample $t$ test, it is obtained the result of $p$-value of $0.466>0.05$ (alpha), meaning that there is no effect or difference of average net income of traditional traders before and after the presence of modern market. The presence of modern market around the traditional one does not have an effect on daily trading profit of traditional market traders because based on the grouping category, there is a decrease and increase in average daily trading profit, this is due to several factors, including that traditional traders have certain strategies to compete with modern market, such as competitive price, quantity of merchandise, and services provided by traditional traders which are more familial. This condition can be seen by the presence of several product variances of modern market that are different from the products sold in traditional market, so that under this condition, the respondents selling different products at traditional market answered that the presence of modern market did not have an effect on their profit.

\section{Quantitative Analysis with Difference-in-Difference (DiD)}

Based on table 5 the evaluation analysis of effect with DiD method, it can be seen that there is a difference in profit, turnover, and number of buyers between treatment and control group. This explains that the presence of modern market, especially those which are close to traditional market (less than $500 \mathrm{~m}$ ) can be the cause of decline in turnover, profit and number of buyers at traditional market. Since traditional market traders are far from modern market (minimarket and supermarket), the decline in profit, turnover and number of buyers is insignificant compared to traditional market close to the modern market. The number of workers in the treatment group only decreased by $0.25 \%$ due to the presence of modern market, while the number of workers in the control group does not change before and after the presence of modern market. Merchandise inventory does not have an effect before and after the presence of modern market. This fact shows that the presence of modern 
market has little effect on the change in number of workers at traditional market and it has no effect on merchandise inventory.

The undeniable fact is that modern market operating close to traditional market (less than 500 $\mathrm{m}$ ) will greatly affect the turnover, profit and number of buyers and traditional market traders. While the modern market which is relatively far away (more than $500 \mathrm{~m}$ ) has insignificant effect on turnover, profit, and the number of buyers of traditional market traders.

\section{Perception Analysis of Traditional and Modern Market Buyers in Cirebon Regency}

Based on Table 6, perception analysis of traditional and modern market buyers on products purchased in traditional and modern markets, it is found that from the sample of 50 traditional market buyers, most of traditional market buyers puchase vegetables by 11 buyers (22.0\%), while from the sample of 65 buyers, modern market buyers purchase other basic needs, such as cosmetics by 21 buyers $(32.3 \%)$.

Table 5. The Effect of Modern Market on Turnover, Profit, Number of Workers, and Merchandise Inventory

\begin{tabular}{lrrc}
\hline Variable & Treatment & Control & Magnitude of Impact \\
\hline Turnover & -14.59 & -6.79 & -7.8 \\
Profit & -16.25 & -6.86 & -9.39 \\
Number of Workers & -2.5 & 0.000 & -2.50 \\
Merchandise Inventory & -16.71 & -4.57 & -12.13 \\
\hline
\end{tabular}

Table 6. Perception Analysis of Traditional and Modern Market Buyers

\begin{tabular}{|c|c|c|c|c|c|}
\hline \multirow{3}{*}{ No. } & \multirow{2}{*}{ Variable } & \multicolumn{2}{|c|}{ Traditional Market } & \multicolumn{2}{|c|}{ Modern Market } \\
\hline & & Amount & Percentage & Amount & Percentage \\
\hline & Products Purchased & & & & \\
\hline 1 & Vegetables & 11 & 22.0 & 4 & 6.2 \\
\hline 2 & Meat & 8 & 16.0 & 1 & 1.5 \\
\hline 3 & Fish & 2 & 4.0 & 0 & 0 \\
\hline 4 & Rice & 7 & 14.0 & 1 & 1.5 \\
\hline 5 & Seasoning & 3 & 6.0 & 5 & 7.7 \\
\hline 6 & Clothes & 6 & 12.0 & 5 & 7.7 \\
\hline 7 & Cooking oil & 4 & 8.0 & 9 & 13.8 \\
\hline 8 & Milk & 3 & 6.0 & 9 & 13.8 \\
\hline 9 & Kitchen equipment & 2 & 4.0 & 0 & 0 \\
\hline 10 & Fruits & 0 & 0 & 10 & 15.4 \\
\hline \multirow[t]{2}{*}{11} & Others & 4 & 8.0 & 21 & 32.3 \\
\hline & Main Reason to Purchase & & & & \\
\hline 1 & Closer distance & 17 & 34.0 & 30 & 46.2 \\
\hline 2 & Low price & 14 & 28.0 & 7 & 10.8 \\
\hline 3 & Negotiable price & 14 & 28.0 & 1 & 1.5 \\
\hline 4 & Good quality of merchandise & 1 & 2.0 & 19 & 29.2 \\
\hline 5 & Seller hospitality & 0 & 0 & 2 & 3.1 \\
\hline \multirow[t]{2}{*}{6} & Complete goods & 4 & 8.0 & 6 & 9.2 \\
\hline & Completeness of Goods & & & & \\
\hline 1 & Complete & 48 & 96.0 & 50 & 76.9 \\
\hline \multirow[t]{2}{*}{2} & Incomplete & 2 & 4.0 & 15 & 23.1 \\
\hline & Building Condition & & & & \\
\hline 1 & Good & 34 & 68.0 & 64 & 98.5 \\
\hline 2 & Needs Improvement & 16 & 32.0 & 1 & 1.5 \\
\hline
\end{tabular}




\begin{tabular}{|c|c|c|c|c|c|}
\hline \multirow{3}{*}{ No. } & \multirow{2}{*}{ Variable } & \multicolumn{2}{|c|}{ Traditional Market } & \multicolumn{2}{|c|}{ Modern Market } \\
\hline & & Amount & Percentage & Amount & Percentage \\
\hline & Products Purchased & & & & \\
\hline & Parking Availability & & & & \\
\hline 1 & Available and adequate & 12 & 24.0 & 45 & 69.2 \\
\hline 2 & Available and inadequate & 34 & 68.0 & 20 & 30.8 \\
\hline \multirow[t]{2}{*}{3} & Not available & 4 & 8.0 & 0 & 0 \\
\hline & Shopping Atmosphere & & & & \\
\hline 1 & Comfortable & 41 & 82.0 & 63 & 96.9 \\
\hline \multirow[t]{2}{*}{2} & Uncomfortable & 9 & 18.0 & 2 & 3.1 \\
\hline & Total & 50 & 100.0 & 65 & 100.0 \\
\hline
\end{tabular}

Most of traditional market buyers stated that the main reason for purchasing at traditional market was due to the close distance by $34.0 \%$, low price by $14 \%$, and negotiable price by $14 \%$, while based on modern market buyers from the sample of 65 buyers, the main reason for purchasing at modern market was due to the close distance by $46.2 \%$ and good quality of merchandise by $29.9 \%$. Seeing from the percentage of the main reason to purchase both at traditional market and modern market, most buyers stated that it was because the close distance, but based on the percentage comparison, it can be determined that the buyers purchasing at modern market due to the close distance was higher than those purchasing at traditional market with the same reason.

Most of buyers stated that the merhandise was complete in traditional market by 48 buyers (96.0\%), while most of buyers with a sample of 65 buyers stated that the merchandise in modern market was complete by 50 buyers (76.9\%). Based on the percentage of merchandise completeness, most of buyers equally stated that the merchandise was complete both at traditional and modern market, but seeing from the percentage comparison, the percentage of buyers stating that the merchandise at traditional market was complete was higher than percentage of buyers stating that the merchandise in modern market was complete.

Most of traditional market buyers stated that the building condition at traditional market was good by 34 buyers (68.0\%), modern market buyers with a sample of 65 buyers stated that the building condition at modern market was good by 64 buyers (98.5\%). Seeing from the percentages of building conditions both at traditional market and modern market, most of buyers equally stated that the building condition was good. However, the percentage comparison indicated that the percentage of buyers stating that the building condition of modern market was good was higher than the percentage of buyers stating that the building condition of traditional market was good.

Most of buyers stated that the parking lot was available and inadequate at traditional market by 34 buyers $(68.0 \%)$, and the modern market buyers with a sample of 65 buyers stated that the parking lot was available and adequate at modern market by 45 buyers (69.2\%).

Most of traditional market buyers stated that shopping atmosphere was comfortable at traditional market by 41 buyers (82.0\%), and the modern market buyers with a sample of 65 buyers stated that shopping atmosphere was comfortable at modern market by 63 buyers (96.9\%). Seeing from the percentages, the buyers stated that the shopping atmospheres both at traditional and modern market were comfortable. But based on the percentage comparison, the buyers stating that the shopping atmosphere at modern market was comfortable was higher than the buyers stating that the shopping at traditional market was comfortable.

\section{Analysis of Strategy of Priority Policy for Increasing Traditional Market Competitiveness and Priority Criteria from Several Aspects in Increasing Traditional Market Competitiveness in Cirebon Regency}

Table 7. explains that the most important strategy in increasing traditional market competitiveness is the Local Government support by $29.43 \%$, followed by the improvement of facilities and infrastructure by $23.96 \%$, the third position is merchandise inventory by $20.60 \%$, followed by finance 
by $15.02 \%$, and the last is market management by $10.98 \%$. The strategy for increasing traditional market competitiveness is the priority of the central government in order to improve the economic growth of the community that should be responded by the local government with strategic measures. The description of the respondents' answers above is in accordance with the wishes of traders and other stakeholders in improving and empowering the economy of small communities. Local government support should be provided with policy/regulatory support and financial support through Local Government Budget (APBD).

Table 7. Priority Assessment on Aspects (First Level) of Traditional Market Development

\begin{tabular}{clc}
\hline No. & First Level & Percentage (\%) \\
\hline 1 & Local Government Support & 29.43 \\
2 & Facilities and Infrastructure & 23.96 \\
3 & Merchandise Inventory & 20.60 \\
4 & Finance & 15.02 \\
5 & Market Management & 10.98 \\
\hline
\end{tabular}

Table 8. Aspects and Criteria in Increasing the Traditional Market Competitiveness in Cirebon Regency

\begin{tabular}{cll}
\hline No. & Aspect (first level) & Criteria (Second Level) \\
\hline 1 & Local Government Support & $\begin{array}{l}\text { Budget Support (funding) } \\
\text { Regulatory Support (policy) }\end{array}$ \\
\hline 2 & Facilities and Infrastructure & $\begin{array}{l}\text { Rejuvenation of Market Building } \\
\text { Improvement of Road Maintenance and Drainage }\end{array}$ \\
\hline 3 & Merchandise Inventory & $\begin{array}{l}\text { Quality Merchandise } \\
\text { Competitive Price of Merchandise }\end{array}$ \\
\hline 4. & Finance & $\begin{array}{l}\text { Working Capital Loan for Traders } \\
\text { Affordable Rental Rate for Business Place }\end{array}$ \\
\hline 5 & Market Management & $\begin{array}{l}\text { Assistance, Guidance and Supervision of Traders } \\
\text { Improvement of Service to Customers } \\
\end{array}$ \\
& & Market Security \\
\hline
\end{tabular}

Table 9. Priority Assessment on Criteria (Second Level) of Traditional Market Development

\begin{tabular}{clc}
\hline No. & Second Level & Percentage (\%) \\
\hline 1 & Budget/Funding Support & 16.58 \\
2 & Regulatory/Policy Support & 12.13 \\
3 & Rejuvenation of Market Building & 11.98 \\
4 & Improvement of Road Maintenance and Drainage & 11.98 \\
5 & Assistance, Guidance and Supervision of Traders & 9.47 \\
6 & Working Capital Loan for Traders & 7.51 \\
7 & Affordable Rent Price of Business Place & 7.51 \\
8 & Improvement of Service to Customers & 7.36 \\
9 & Quality Merchandise & 5.49 \\
10 & Competitive Price & 5.49 \\
11 & Market Security & 3.77 \\
\hline
\end{tabular}

\section{CONCLUSION}

(1) T-test result on profit and turnover was performed on traditional market traders before and after the presence of modern market, the result indicated that the presence of modern market did not have an effect on profit and turnover of traditional market traders. Meanwhile, the number of buyers, number of workers, ways to attract buyers, and 
merchandise inventory had an effect on traditional market traders after the presence of modern market. It was found that the presence of modern market had an effect on the number of workers, number of buyers, ways to attract buyers, and merchandise inventory of traditional market traders.

(2) The result of analysis using DiD (Difference-in-Difference) method indicated a decline in average turnover experienced by traditional market traders reaching $(-7.8 \%)$, the decline in average profit experienced by traditional market traders reached $(-9.39 \%)$, meanwhile there was also a decline in the average number of buyers reaching $(-12.3 \%)$.

(3) The analysis result of traditional and modern market buyer perception indicated the majority of respondents answered that the main reason to purchase in either traditional market or modern market was because the market distance was close to their home. If the distance between traditional market and modern market are too close, then there will be unhealthy competition because the majority of buyers at traditional market and modern market take into account the distance in shopping.

(4) The result of analytical hierarchy process (AHP), for an increase of traditional market competitiveness consisting of several aspects, indicated that the priority of measure to be taken in the first place was local government support (30.46\%), followed by facilities and infrastructure $(22.06 \%)$, market management $(18.58 \%)$, finance $(16.67 \%)$, and merchandise inventory had a priority scale of (12.22\%).

\section{REFERENCES}

Agung, A. (2013). Analysis of determinants of consumer preference in shopping to traditional markets in Denpasar City: Factor analysis. Journal of Applied Quantitative Economic, 6(1), 4145.

Al, E. (2013). Efforts to maintain traditional market existence: Study of revitalization of the Piyungan Bantul Traditional Market. Journal of PMI, 10(2), 63-78.

Alfanita, E., Wijaya, A. and Siswidyanto. (2015). Revitalization of traditional markets in the perspective of good governance: Study in the Malang Tumpung Market. Journal of Public Administration, 3(5), 758-762.

Arikunto, S. (2013). Research procedure: A practical approach. Jakarta: Rineka Cipta.

Damardjati, D. (2011). Strategy for developing the domestic domestic market in facing global competition. Food Crop Science and Technology, 6(2), 152-167.

Haryotejo, B. (2014). Impact of hypermarket expansion on traditional markets in regions. Journal of Bina Praja, 6(3), 237-248.

Hermuningsih, S., Sumartiah, S., and Wardani, D.K. (2016). Development strategy analysis: Creative industry. Journal of Yogyakarta City BAPPEDA Research, 143-153.

Paramita, A. and Ayuningsasi, A. (2013). Effectiveness and impact of traditional market revitalization programs at Paninjoan Agung Market. E-Journal of EP Unud, 2(5); 233-243.

Pradipta, A. and Wirawan, I. (2016). The influence of traditional market revitalization and merchant resources on the performance of market traders in Denpasar City. E-Journal of EP, 5(4), 460479. 